\title{
Understanding clopidogrel efficacy in the presence of cytochrome $\mathrm{P}_{\mathbf{4}} 5^{\circ}$ polymorphism
}

\author{
Jacques Turgeon, Chantal Pharand, Véronique Michaud
}

$\infty \quad$ See related article page I7I5

I $\mathrm{n}$ this issue, Suh and colleagues report on the risk of atherothrombotic events in people taking clopidogrel. ${ }^{1}$ Their main objective was to link clopidogrel efficacy to the activity of a specific $\mathrm{CYP}_{3} \mathrm{~A}$ isoenzyme, namely $\mathrm{CYP}_{3} \mathrm{~A}_{5}$, in people with 2 different $\mathrm{CYP}_{3} \mathrm{~A}_{5}$ genotypes. The rationale for their study is based on the fact that clopidogrel is a prodrug that requires metabolism by $\mathrm{CYP}_{3} \mathrm{~A}_{4}$ and $\mathrm{CYP}_{3} \mathrm{~A}_{5}$ before it can be active. ${ }^{2-4}$ Therefore, Suh and colleagues conducted their study to shed light on a broader, controversial issue: Is decreased $\mathrm{CYP}_{3} \mathrm{~A}_{5}$ activity that is due to drug-drug interactions or genetic polymorphisms associated with a clinically significant decrease in clopidogrel efficacy?

In phase I of their study, Suh and colleagues enrolled I6 healthy volunteers with the $C Y P_{3} A_{5}$ expressor genotype $\left({ }^{\star} \mathrm{I} /{ }^{\star} \mathrm{I}\right.$ or ${ }^{\star}{ }_{\mathrm{I}} /{ }^{\star} 3$ allele) and $\mathrm{I} 6$ with the $\mathrm{CYP}_{3} \mathrm{~A}_{5}$ non-expressor genotype $\left({ }^{\star} 3 l^{\star} 3\right.$ allele). They then gave them two 7 -day courses of clopidogrel; the second course was preceded by a 4-day course of itraconazole, a selective $\mathrm{CYP}_{3} \mathrm{~A}_{4}$ inhibitor. Inhibition of $\mathrm{CYP}_{3} \mathrm{~A}_{4}$ by itraconazole in the subjects who lacked $\mathrm{CYP}_{3} \mathrm{~A}_{5}$ was associated with a significant decrease in clopidogrel activity, whereas some activity (about 25\%) was preserved in those with the $\mathrm{CYP}_{3} \mathrm{~A}_{5}$ expressor genotype.

In phase 2 of their study, Suh and colleagues observed the frequency of atherothrombotic events (cardiac death, myocardial infarction and nonhemorrhagic stroke) in a 6-month follow-up period among 348 patients who underwent coronary angioplasty with bare-metal stent implantation and antiplatelet therapy with clopidogrel. They found that such events occurred more frequently among the patients who had the $C Y P_{3} A_{5}$ nonexpressor genotype (I4/I93) than among those with the expressor genotype (3/155). Results from both phases of their study suggest that decreased metabolism of clopidogrel to its active form is associated with decreased clinical efficacy of the drug.

In 2003, Lau and colleagues showed that, in 44 patients undergoing percutaneous coronary intervention (PCI) with stent implantation, concomitant treatment with atorvastatin, a $\mathrm{CYP}_{3} \mathrm{~A}$ substrate, was associated with reduced antiplatelet activity of clopidogrel. ${ }^{5}$ They also showed a reduction in clopidogrel's antiplatelet activity associated with the use of erythromycin and troleandomycin, 2 potent $\mathrm{CYP}_{3} \mathrm{~A}$ inhibitors; however, use of rifampin, a $\mathrm{CYP}_{3} \mathrm{~A}$ inducer, was associated with enhanced antiplatelet activity. To confirm these observations, Lau and colleagues conducted another study, in which they found further evidence of a relationship between $\mathrm{CYP}_{3} \mathrm{~A}_{4}$ activity and clopidogrel activity. ${ }^{6}$ Neubauer and associates observed in 47 patients undergoing elective PCI that pretreatment with atorvastatin or simvastatin was associated with a reduction in clopidogrel effects. ${ }^{7}$ Others also observed a lower efficacy of clopidogrel in healthy volunteers taking certain statins but not others. ${ }^{8}$

It is noteworthy that the results reported by Lau and colleagues ${ }^{5}$ were questioned because of their use of nonstandard platelet function assays. As well, a number of prospective clinical trials and retrospective epidemiologic studies failed to show a clinically significant interaction between clopidogrel and statins. ${ }^{9-17}$ However, several of these studies had major limitations: they considered all statins, not only those that are $\mathrm{CYP}_{3} \mathrm{~A}$ inhibitors, and they did not take into account in their control groups the concomitant intake of various $\mathrm{CYP}_{3} \mathrm{~A}$ substrates (e.g., calcium-channel blockers, antidepressants, benzodiazepines, macrolide antibiotics, imidazole antifungals) that can modulate clopidogrel activity.

The study of genetic contributions to drug action, including pharmacokinetics and pharmacodynamics, may help to improve the efficacy and safety of drugs. Of the CYP enzymes, the $\mathrm{CYP}_{3} \mathrm{~A}$ enzymes are the most relevant, catalyzing the biotransformation of more than $50 \%$ of currently used therapeutic drugs. Consequently, variations in $\mathrm{CYP}_{3} \mathrm{~A}$ activity can affect the efficacy and safety of drugs metabolized by these isoenzymes. Many research groups have failed to show an association between $\mathrm{CYP}_{3} \mathrm{~A}_{4}$ variants and enzyme activity. In contrast, $\mathrm{CYP}_{3} \mathrm{~A}_{5}$ is polymorphically expressed and shows marked differences between ethnic populations. ${ }^{18-20}$ Single nucleotide polymorphisms $\mathrm{CYP}_{3} \mathrm{~A}_{5}{ }^{\star} 3$ and $C Y P_{3} A_{5}{ }^{\star} 6$ lead to alternative splicing and protein truncation, which results in the absence of $\mathrm{CYP}_{3} \mathrm{~A}_{5}$ from tissues. ${ }^{19-21}$ When $\mathrm{CYP}_{3} \mathrm{~A}_{5}$ is expressed (in subjects with at least one $C Y P_{3} A_{5}{ }^{\star} I$ allele), this protein may account for more than $50 \%$ of the total $\mathrm{CYP}_{3} \mathrm{~A}$ activity in the liver. ${ }^{19}$

Suh and colleages used itraconazole to selectively inhibit $\mathrm{CYP}_{3} \mathrm{~A}_{4}$ while preserving some activity in subjects with the $C Y P_{3} A_{5}{ }^{\star}$ allele. Studies of in vitro drug metabolism have shown that only $\mathrm{CYP}_{3} \mathrm{~A}_{4}$ catalyzes the biotransformation of itraconazole, whereas $\mathrm{CYP}_{3} \mathrm{~A}_{5}$ exhibits no catalytic capabilities. ${ }^{22}$ $\mathrm{Yu}$ and associates found that subjects with the $C Y P_{3} A_{5}{ }^{\star} I$ allele were less susceptible to changes in systemic clearance of midazolam during inhibition by itraconazole than were subjects with similar total $\mathrm{CYP}_{3} \mathrm{~A}$ activity but who had $\mathrm{CYP}_{3} \mathrm{~A}_{5}{ }^{\star} 3$ alleles. ${ }^{23}$ These results suggest that itraconazole is an appropriate tool to selectively inhibit $\mathrm{CYP}_{3} \mathrm{~A}_{4}$ activity and not $\mathrm{CYP}_{3} \mathrm{~A}_{5}$ activity. 
The active metabolite of clopidogrel irreversibly blocks $\mathrm{P}_{2} \mathrm{Y}_{12}$ receptors on the platelet surface, which inhibits adenosine diphosphate (ADP)-induced platelet aggregation. ${ }^{24,25}$ Hence, in addition to $\mathrm{CYP}_{3} \mathrm{~A}_{5}$ polymorphisms, mutations in the $\mathrm{P}_{2} \mathrm{Y}_{12}$ gene may also account for the variability in clopidogrel efficacy. Three single-nucleotide polymorphisms and a single-nucleotide insertion polymorphism in the $\mathrm{P}_{2} \mathrm{Y}_{12}$ gene define 2 haplotypes: patients with a $\mathrm{H}_{2}$ haplotype have been found to exhibit increased maximal platelet aggregation in response to ADP and possibly a lesser response to drugs such as clopidogrel. ${ }^{26}$ This potential genetic variability in the pharmacodynamics of clopidogrel was not taken into account in the study by Suh and colleagues.

Platelets play an important role in the pathogenesis of atherothrombotic events. Patients undergoing PCI with stent implantation are at an increased risk of thrombosis sometimes complicated by acute myocardial infarction or death. It is estimated that more than I million PCI procedures are performed annually worldwide and that most (70\%) involve stent implantation. ${ }^{27}$ Currently, the American Heart Association/ American College of Cardiology recommends that all patients undergoing PCI with implantation of a bare-metal stent receive dual antiplatelet therapy, with ASA and a thienopyridine, for at least I month after the procedure ( $3-6$ months for drugeluting stents), and ideally up to $\mathrm{I} 2$ months in patients who are not at high risk of bleeding. ${ }^{27}$

The results reported by Suh and colleagues represent significant clinical findings that clearly call for well-designed, prospective, pharmacogenetic, drug-drug interaction studies to ascertain clopidogrel's efficacy in patients with various genotypes receiving treatment with $\mathrm{CYP}_{3} \mathrm{~A}$ substrates.

Besides inhibition of $\mathrm{CYP}_{3} \mathrm{~A}$, other reasons, such as impaired intestinal absorption ${ }^{28,29}$ dose- and time-dependency ${ }^{30}$ and post-treatment platelet reactivity, ${ }^{31}$ should be evaluated to gain a complete understanding of the variability observed in clopidogrel action.

\section{This article has been peer reviewed.}

All of the authors are with the Faculté de pharmacie, Université de Montréal, Montréal, Que.

Competing interests: None declared for Chantal Pharand or Véronique Michaud. Jacques Turgeon has received speaker fees from Pfizer Canada.

Contributors: All of the authors contributed substantially to the analysis of the data and the writing of the manuscript, and all approved the final version.

\section{REFERENCES}

I. Suh JW, Koo BK, Zhang SY, et al. Increased risk of atherothrombotic events associated with cytochrome $\mathrm{P}_{45} \mathrm{O}_{3} \mathrm{~A} 5$ polymorphism in patients taking clopidogrel. CMAJ 2006;174(I2):1715-22.

2. Savi P, Herbert JM, Pflieger AM, et al. Importance of hepatic metabolism in the antiaggregating activity of the thienopyridine clopidogrel. Biochem Pharmacol I992;44:527-32.

3. Herbert JM, Savi P, Maffrand JP. Biochemical and pharmacological properties of clopidogrel: a new ADP receptor antagonist. Eur Heart J I999;(Suppl I):A3I-40.

4. Clarke TA, Waskell LA. The metabolism of clopidogrel is catalyzed by human cytochrome $\mathrm{P}_{4}{ }^{\circ} 3 \mathrm{~A}$ and is inhibited by atorvastatin. Drug Metab Dispos 2003;31:53-9.

5. Lau WC, Waskell LA, Watkins PB, et al. Atorvastatin reduces the ability of clopidogrel to inhibit platelet aggregation: a new drug-drug interaction. Circulation 2003 I07:32-7.
6. Lau WC, Gurbel PA, Watkins PB, et al. Contribution of hepatic cytochrome P450 $3 \mathrm{~A} 4$ metabolic activity to the phenomenon of clopidogrel resistance. Circulation 2004;109:I66-7I

7. Neubauer H, Gunesdogan B, Hanefeld C, et al. Lipophilic statins interfere with the inhibitory effects of clopidogrel on platelet function - a flow cytometry study. Eur Heart J 2003;24:1744-9.

8. Mach F, Senouf D, Fontana P, et al. Not all statins interfere with clopidogrel during antiplatelet therapy. Eur J Clin Invest 2005;35:476-8I.

9. Muller I, Besta F, Schulz C, et al. Effects of statins on platelet inhibition by a high loading dose of clopidogrel. Circulation 2003;108:2195-7.

Io. Serebruany VL, Midei MG, Malinin AI, et al. Absence of interaction between atorvastatin or other statins and clopidogrel: results from the interaction study. Arch Intern Med 2004;164:205I-7.

II. Mitsios JV, Papathanasiou AI, Rodis FI, et al. Atorvastatin does not affect the antiplatelet potency of clopidogrel when it is administered concomitantly for 5 weeks in patients with acute coronary syndromes. Circulation 2004;109:1335-8.

I2. Gorchakova O, von BN, Gawaz M, et al. Antiplatelet effects of a $600 \mathrm{mg}$ loading dose of clopidogrel are not attenuated in patients receiving atorvastatin or simvastatin for at least 4 weeks prior to coronary artery stenting. Eur Heart J 2004;25:1898-902.

I3. Hochholzer W, Trenk D, Frundi D, et al. Time dependence of platelet inhibition after a 6oo-mg loading dose of clopidogrel in a large, unselected cohort of candidates for percutaneous coronary intervention. Circulation 2005;111:2560-4.

I4. Smith SM, Judge HM, Peters G, et al. Multiple antiplatelet effects of clopidogrel are not modulated by statin type in patients undergoing percutaneous coronary intervention. Platelets 2004;15:465-74.

I5. Serebruany VL, Malinin AI, Callahan KP, et al. Statins do not affect platelet inhibition with clopidogrel during coronary stenting. Atherosclerosis 200I;159:239-4I.

I6. Saw J, Steinhubl SR, Berger PB, et al. Lack of adverse clopidogrel-atorvastatin clinical interaction from secondary analysis of a randomized, placebo-controlled clopidogrel trial. Circulation 2003;108:92I-4.

I7. Wienbergen H, Gitt AK, Schiele R, et al. Comparison of clinical benefits of clopidogrel therapy in patients with acute coronary syndromes taking atorvastatin versus other statin therapies. Am J Cardiol 2003;92:285-8.

I8. Lee SJ, Usmani KA, Chanas B, et al. Genetic findings and functional studies of human $\mathrm{CYP}_{3} \mathrm{~A}_{5}$ single nucleotide polymorphisms in different ethnic groups. Pharmacogenetics 2003;13:46I-72.

I9. Kuehl P, Zhang J, Lin Y, et al. Sequence diversity in $\mathrm{CYP}_{3} \mathrm{~A}$ promoters and characterization of the genetic basis of polymorphic $\mathrm{CYP}_{3} \mathrm{~A}_{5}$ expression. Nat Genet 200I; 27:383-91.

20. Van Schaik RH, van der Heiden IP, van den Anker JN, et al. CYP3 $\mathrm{A}_{5}$ variant allele frequencies in Dutch Caucasians. Clin Chem 2002;48:I668-7I.

2I. Hustert E, Haberl M, Burk O, et al. The genetic determinants of the $\mathrm{CYP}_{3} \mathrm{~A}_{5}$ polymorphism. Pharmacogenetics 200I;II:773-9.

22. Isoherranen $\mathrm{N}$, Kunze $\mathrm{KL}$, Allen $\mathrm{KE}$, et al. Role of itraconazole metabolites in $\mathrm{CYP}_{3} \mathrm{~A}_{4}$ inhibition. Drug Metab Dispos 2004;32:II2I-3I.

23. Yu KS, Cho JY, Jang IJ, et al. Effect of the $\mathrm{CYP}_{3} \mathrm{~A}_{5}$ genotype on the pharmacokinetics of intravenous midazolam during inhibited and induced metabolic states. Clin Pharmacol Ther 2004;76:104-I2.

24. Pereillo JM, Maftouh M, Andrieu A, et al. Structure and stereochemistry of the active metabolite of clopidogrel. Drug Metab Dispos 2002;30:1288-95.

25. Ding Z, Kim S, Dorsam RT, et al. Inactivation of the human $\mathrm{P}_{2} \mathrm{Y}_{12}$ receptor by thiol reagents requires interaction with both extracellular cysteine residues, Cysi7 and Cys270. Blood 2003; I0I:3908-14.

26. Fontana P, Dupont A, Gandrille S, et al. Adenosine diphosphate-induced platelet aggregation is associatged with $\mathrm{P}_{2} \mathrm{Y}_{12}$ gene sequence variations in healthy subjects. Circulation 2003; 108:989-95.

27. Smith SC Jr, Feldman TE, Hirshfeld JW Jr, et al; American College of Cardiologyl American Heart Association Task Force on Practice Guidelines; ACC/AHA/SCAI Writing Committee to Update 200I Guidelines for Percutaneous Coronary Intervention. ACC/AHA/SCAI 2005 guideline update for percutaneous coronary intervention: a report of the American College of Cardiology/American Heart Association Task Force on Practice Guidelines (ACC/AHA/SCAI Writing Committee to Update $200 \mathrm{I}$ Guidelines for Percutaneous Coronary Intervention). Circulation 2006;II3:eI66-286.

28. Taubert D, Kastrati A, Harlfinger S, et al. Pharmacokinetics of clopidogrel after administration of a high loading dose. Thromb Haemost 2004;92(2):3II-6.

29. Von Beckerath N, Taubert D, Pogatsa-Murray G, et al. Absorption, metabolization, and antiplatelet effects of 300-, 600-, and 900-mg loading doses of clopidogrel: results of the ISAR-CHOICE (Intracoronary Stenting and Antithrombotic Regimen: Choose Between 3 High Oral Doses for Immediate Clopidogrel Effect) Trial. Circulation 2005;II2(I9):2946-50.

30. Muller I, Seyfarth M, Rudiger S, et al. Effect of a high loading dose of clopidogrel on platelet function in patients undergoing coronary stent placement. Heart 200I; 85(I):92-3.

31. Gurbel PA, Bliden KP, Hiatt BL, et al. Clopidogrel for coronary stenting: response variability, drug resistance, and the effect of pretreatment platelet reactivity. Circulation 2003;I07(23):2908-I3.

Correspondence to: Dr. Jacques Turgeon, Faculté de Pharmacie, Université de Montréal, CP 6128 succursale Centre ville, Montréal QC H3 $\mathrm{H}_{3} \mathrm{J7}$; fax 5I4 343-2098; jacques.turgeon@umontreal.ca 